\title{
DECLARAÇÃO DE CONFLITO DE INTERESSES
}

Esta declaração deve ser preenchida, assinada e enviada através do passo 4 do processo de submissão.

A submissão de qualquer manuscrito só será completa mediante o recebimento da carta de submissão e da declaração de conflito de interesse. Portanto, nenhum artigo será publicado na Revista Univap sem o preenchimento desses requisitos.

Nome do artigo: Os Herschel e suas mentes brilhantes

\section{Fontes de financiamento da pesquisa:}

Informar abaixo de onde vieram os recursos para realização da pesquisa: agências de fomento de pesquisa, organizações e instituições sem fins lucrativos, incentivo próprio, patrocínio privado.

[ ] O presente estudo foi financiado por

[ ] O presente estudo foi parcialmente financiado por

[X ] O presente estudo não teve fontes de financiamento externas.

\section{Definicão de conflito de interesse:}

São considerados potenciais conflitos de interesse, a relação de um autor, diretamente, ou indiretamente através da instituição promotora da pesquisa, com empresas que eventualmente possam se beneficiar dos resultados do estudo.

Os seguintes tipos de relação são considerados como potencialmente conflitantes e devem ser obrigatoriamente declarados:

Se nos últimos cinco anos um dos autores:

1) Recebeu honorários de consultoria, palestras, redação de textos ou quaisquer outros tipos de serviços remunerados prestados pelo fabricante de produto envolvido no estudo.

2) Recebeu auxílio do fabricante de produto envolvido no estudo (verbas de pesquisa, fornecimento de equipamentos, drogas, mão de obra) relacionados ao estudo em análise ou outro estudo que envolva o mesmo produto.

3) Recebeu auxílio de fabricante de produto envolvido no estudo para participação em congressos.

4) Deteve ações do fabricante de produto envolvido no estudo.

5) Houve envolvimento do fabricante de produto envolvido no estudo na coleta, análise, interpretação ou redação dos dados.

6) É empregado ou presta serviços a empresa que possa se beneficiar direta ou indiretamente com os resultados do estudo.

\section{Potenciais conflitos de interesse dos autores:}

Cada autor deve preencher o nome na lista abaixo, declarar se apresenta algum potencial conflito de interesses, e assinar. Atenção: caso seja impossível ao autor responsável pela submissão coletar assinaturas de todos os co-autores, os mesmos devem enviar sua própria cópia assinada dessa declaração para o e-mail revista@univap.br.

Em caso de um número de autores maior do que o incluído abaixo, favor reproduzir a segunda página dessa declaração. 
Autor : Caren Lorensi

[X ] Não há conflitgcom o presente artigo.

[ ] Potencial confros:

Assinatura:

Autor:

[X Não há conflito com o presente artigo.

[ ] Potencial conflito:

Assinatura:

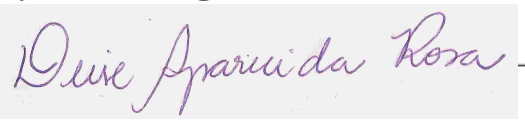

Autor:

[ ] Não há conflito com o presente artigo.

[ ] Potencial conflito:

\section{Assinatura:}

Autor:

[ ] Não há conflito com o presente artigo.

[ ] Potencial conflito:

\section{Assinatura:}

Autor:

[ ] Não há conflito com o presente artigo.

[ ] Potencial conflito:

\section{Assinatura:}

Autor:

[ ] Não há conflito com o presente artigo.

[ ] Potencial conflito:

\section{Assinatura:}

Autor:

[ ] Não há conflito com o presente artigo.

[ ] Potencial conflito:

\section{Assinatura:}

Autor:

[ ] Não há conflito com o presente artigo.

[ ] Potencial conflito:

\section{Assinatura:}

Autor:

[ ] Não há conflito com o presente artigo.

[ ] Potencial conflito:

\section{Assinatura:}

Autor:

[ ] Não há conflito com o presente artigo.

[ ] Potencial conflito: 